\title{
DEEP-WATER EXPLORATORY BOTTOM LONG LINING IN THE WATERS OF THE ARAFURA SEA
}

\author{
Badrudin*), Ngurah N.Wiadnyana**), and Berbudi Wibowo**)
}

\begin{abstract}
Bottom long line fisheries in the continental shelf area of the Arafura Sea has have practised and developed since the last two decades. But bottom long lining in the slope area seemed to be unusual fishing operation for most Indonesian fishers as this fishing activity facing a relatively higher risks of fishing gear lost. Based on exploratory bottom long lining that randomly operated, it was later found that 16 fishing stations were carried out in the flat part of the continental shelf area and 13 stations in the slope area. Catch rate in the slope area of about 1.3 tonnes/setting was more than four and half times higher than the catch rate in the flat area which was only about 0.28 tonnes. Higher variation of catch/setting in the flat area was occurred, while in the slope area was relatively lower. The hook rate in the flat area was only 1.02 (one fish) or $2.8 \mathrm{kgs}$, while in the slope area was 5.63 (6 fish) or $14.2 \mathrm{kgs}$ per 100 hooks. From these composition data it can be concluded that more than $75 \%$ of bottom long line catches consisted of red snappers, groupers, sharks, and rays. The most dominated red snappers species found in the catch were goldband snappers and jobfish, Etelis carbunculus. The average individual size of red snappers in the slope area was likely to be bigger compare with those inhabiting the flat area. On the other hand, the individual size of groupers inhabiting the flat area seem to be bigger compare with those inhabiting the slope area. Similarly the bigger average individual sizes of cobia and sharks and rays were likely occurred in the flat area. From this earlier aspect it is likely that the demersal fish resources in the slope area was relatively lightly exploited or perhaps it was still provide a pristine area as almost no trawlers carried out fishing operation in this area.
\end{abstract}

KEYWORDS: deep-water demersal fish, bottom long line, continental shelf area, slope area, Arafura Sea, red snappers, groupers, cobia, shark, and rays

\section{INTRODUCTION}

The demersal fish resources in the continental shelf area of the Arafura Sea have been exploited since the $1960^{\text {th }}$ in the form of exploratory trawling. Later, these exploratory activities were then transformed into the Indonesian-Japan joint venture companies. The main target of these exploitations were the penaeid shrimp resources (Unar \& Naamin, 1984). As already acknowledged, the shrimp ground usually the relativelly shallow waters with relativelly flat bottom condition characterized by lower salinity as a result from run-off and river discharges with muddy substrates. Due to the shrimp as the target group of fishing, trawling activities targetted on fish resources in the deeper waters of more then $100 \mathrm{~m}$ until recently was rarely found, so that the fish resources in these areas are considered lightly exploited.

From the statistical catch and effort data analysis combined with the results of stock assessment works during the previous years showed that the level of exploitation of fish resources especially shrimp and demersal fish in the Arafura Sea was approaching fully exploited (Badrudin \& Sumiono, 2002). These were reflected by the recorded demersal fish productions that had been reaching or around the maximum sustainable yield (Badrudin et al., 2002; Badrudin et al., 2004; Badrudin et al., 2004a). This was due to the lower activities and migrations (Aoyama, 1973), causing higher vulnerability to fishing pressure. As a result, if the fishing effort increased or doubled will lead to the increased of fishing mortality and finally decresed the catch per unit effort as an index of abundance (Gulland, 1993).

In search of new resources and fishing grounds, the Research Center for Capture Fisheries in collaboration with a private fishing company based in Jakarta carried out an exploratory bottom long lining survey in the Arafura Sea covering both the continental shelf flat and slope areas and a wide range of depth started from around $30 \mathrm{~m}$ to approximately $700 \mathrm{~m}$. As it was already known that bottom long line provide one of the selective fishing gears used to catch the relatively large and economically important demersal fin fish, such as red snappers and groupers. It was acknowledged that bottom long line fisheries in the continental shelf area of the Arafura Sea has been practised and developed since the last two decades.

\section{MATERIALS AND METHODS}

Data analyzed were part of the results obtained during the exploratory bottom long lining reported by Wibowo (2004). Bottom long line fishing activities were carried out in the continental shelf area of the Arafura Sea, using M/V Ural, a Russian fishing vessel chartered by the Indonesian fishing company based in Jakarta. The activity was carried out in May-July 2004 and the fishing ground is depicted in Figure 1. Fishing gear used was bottom long line with the number of hook between 6,900 to more than 11,000 hooks, with

\footnotetext{
*) Research Institute for Marine Fisheries, Ministry of Marine Affairs and Fisheries Muara Baru, Jakarta

**) Research Center for Capture Fisheries, Ministry of Marine Affairs and Fisheries Ancol, Jakarta
} 
the distance between hooks was about one meter. With the large number of hooks, the setting time will last some hours and therefore the number of setting was only once per day. Fishing activity in the Arafura Sea during this cruise was about 29 effective fishing days, so that the total numbers of setting was 29 sets. Bottom long line was randomly set covering the bottom area of both the continental shelf part which relatively flat bottom conditions and the slope part of the Arafura Sea. The catches were sorted and weighted. Sorting fish was carried out whenever possible up to species, genus or family.

\section{Description of Fishing Gear}

The so called a Spanish type of bottom long line has been used throughout the period of exploratory fishing. In principle this type was similar to that of bottom long line used by most Indonesian fishers. The difference was that in the construction and the number of hooks, so that this Spanish type can be operated in the deeper waters up to $1,000 \mathrm{~m}$ depth. This type having two different diameter main lines. The number of sinkers was more than the number of floats, so that most of the hooks were expected to lay down on the bottom. The main parts of the bottom long line were consisted of two main lines, balisa, retinida, aparekho, angkla, and parantingo.

One of the two main lines called retinida, a $3 / 4$ inches diameter poly filament rope was used. This retinida was operated to pull the bottom long line by the winch through line hauler to handle the heavy burden and make the line hauling more easily. Balisa is a buoy like float with bright in colour working not only as a float but also as a mark mounted on the tip of bottom long line, so that it is easier to be searched. The balisa is rounded globe with diameter of approximately $0.5 \mathrm{~m}$ marked with bright colour. In a certain condition such as heavy waves and bad weathers where searching balisa was difficult, a radio buoy has been used. The poly filament rope of $3 / 4$ inches diameter connecting balisa and anchor was used while the length was varied depending upon the waters depth. Aparekho is a $1 / 4$ inches diameter poly filament rope provide part of the main line and connected with the branch line by a swivel. During the hooks hauling, aparekho was pull through line hauler. At the tip of the bottom long line, an angkla that functioning as an anchor was mounted. This angkla was used as both sinkers and to keep the hooks firmed from any movement. Parantingo is the connecting line between retinida and aparekho. Every 69 hooks and 3 sinkers a retinida was connected with aparekho through parantingo. Parantingo is made of poly filament with $3 / 4$ inches diameter and length of about $25 \mathrm{~m}$. Branch line is a mono filament rope of about one meter length. The distant between each branch lines was one meter, so that the distant between each hook was also one meter. With this arrangement, the length of one unit bottom long line operated during the survey cruise was between 6-11 $\mathrm{km}$, while the hook used was No. 9.

Sinker is made from a concrete cement of $5 \mathrm{kgs}$ weight and is connected with aparekho using one meter length rope. Each sinker was set continuosly along the main line every 23 hooks.

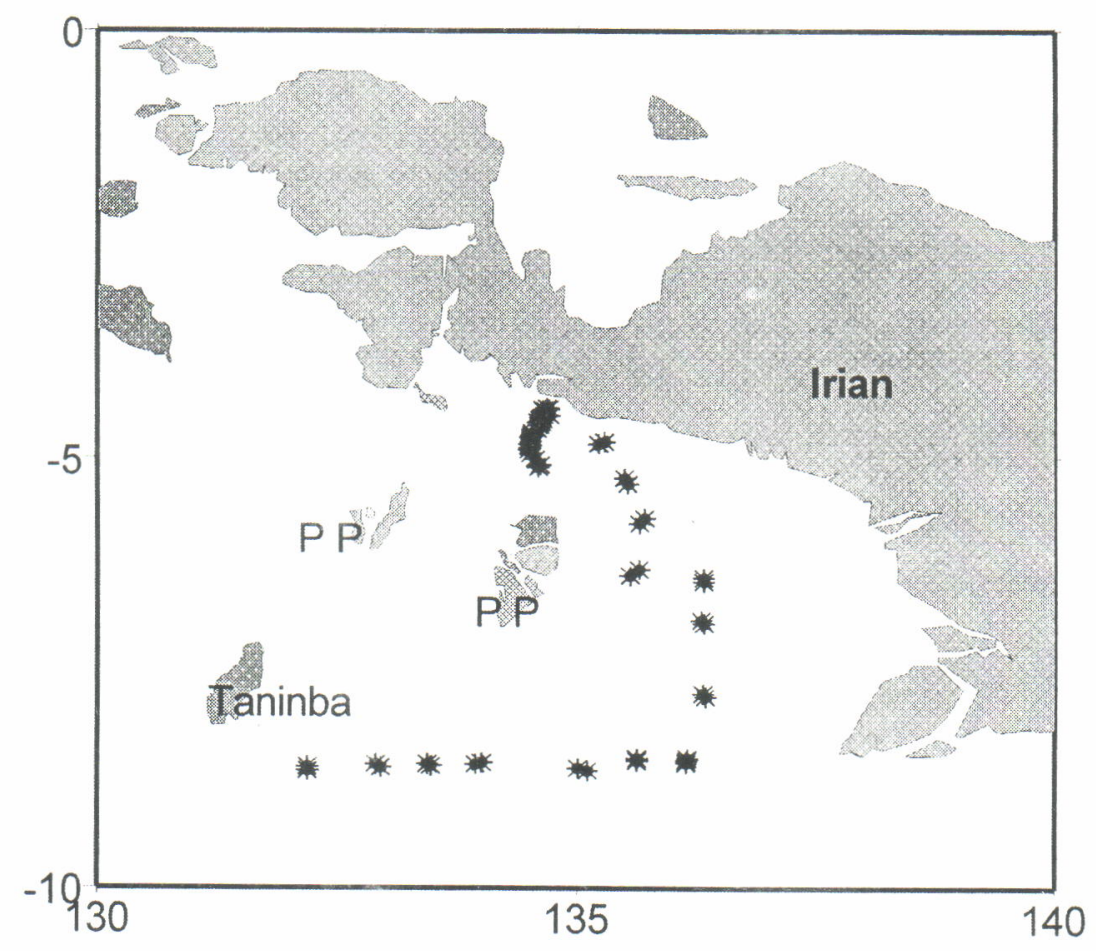

Figure 1. Bottom long line fishing sites in the Arafura Sea 


\section{RESULTS AND DISCUSSION}

From a total of 29 bottom long line fishing station that randomly operated, it was later found that 16 fishing stations were in the flat part of the continental shelf area and 13 fishing stations had been carried out in the continental slope area. Bottom long lining in the slope area seemed to be unusual fishing operation for most Indonesian fishers as this fishing activity facing a relatively higher risks of fishing gear lost, due to the hooks troubles and caught by corals stones beside it was believed that the fish in such an area would not be found in school and difficult to catch.

\section{Catch and Catch Rate Distribution}

The availability of catch and catch rate data provide one of fisheries indicators representing the stock abundance of fish resources in the area. The minimum and maximum catch/setting in the flat area were $30 \mathrm{kgs}$ and $926 \mathrm{kgs}$ respectively, while in the slope area were $816 \mathrm{kgs}$ and $1918 \mathrm{kgs}$.
The total number of hooks used in the flat area was almost one and half times higher than in the slope area, while the overall total catch in the slope area was almost four times higher than the catch obtained in the flat area. The overall total catch in the slope area was about 16,917 kgs (approx. 17.0 tonnes) while the catch in the flat area was only 4.5 tonnes. Similarly, the catch rate in the slope of about 1.3 tonnes was more than four and half times higher that the catch rate in the flat area which was only about 0.28 tonnes. Higher variation of catch/setting in the flat area was occurred, while in the slope area was relatively lower. Looking at the confidence limits of the mean catch rates, it is undoubtedly that the difference between the two means was highly significant (Table 1).

Another term used for the index of abundance in the bottom long line fisheries is hook rate. The standard hook rate is define as the number of fish caugth per 100 hooks per setting. Based on the catch data in both number of fish $(N)$ and weight $(W)$, the

Table 1. Total catch and hook rates of bottom long line in the flat and slope bottom area of the Arafura Sea

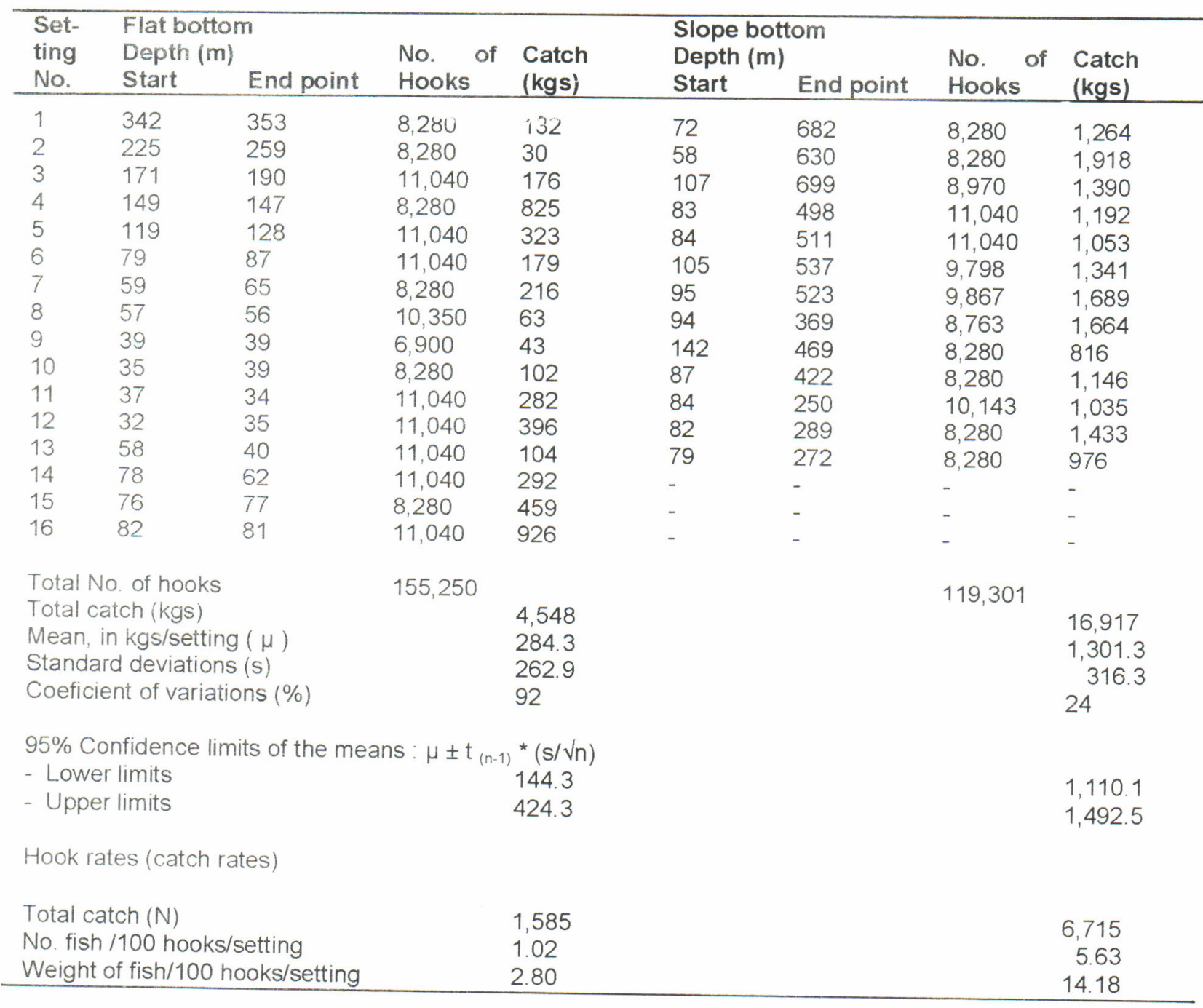


hook rates of the bottom long line fishery for the flat and slope area of the Arafura Sea can be calculated. As can be seen in Table 1, the hook rate in the flat area was only 1.02 , while in the slope area was 5.63 . Implications from these figures, it can be expected that bottom long line operations in the slope area of the Arafura Sea will get 6 (six) fish per 100 hooks, while in the flat area will only get 1 (one) fish. Similar comparison in term of weight can also be applied, where in the flat area bottom long lining will only get $2.8 \mathrm{kgs}$ fish $/ 100$ hooks, while in the slope area about $14.2 \mathrm{kgs}$ fish can be expected

From tnis aspect it is likely that the demersal fis' resources in the slope area was relatively lightly exploited or perhaps it was still provide a pristine area as almost no fish-net trawlers carried out fishing operation in this area due to the bottom conditions that provided untrawlable ground. Demersal fish trawling in the slope area would be difficult to be handled as this gear is designed to operate in the relatively flat bottom condition, so that the trawling will lead to the unproperly set of the gear.

\section{Catch Composition}

Data and information on catch composition reflect species diversity of fish community. Fluctuation occurred in the long term catch composition indicates some responses of the community againts external factors affecting the dynamics of the fish community.

During this exploratory fishing, it is likely that bottom long line provides a very selective fishing gear. This was reflected by the relatively lower species diversity of fish catch beside this bottom long line only targeted on some relatively large size of fish. In the context of the implementation of the Code of Conduct for Responsible Fisheries (FAO, 1995), the use of bottorn long line for large demersal finfish exploitation in some cases is more permisible compared with the use of trawl net. As can be traced from the catch composition by major catagories data, more than $90 \%$ bottom long line catches during this survey consisted only of about 4 major fish groups, these are the red snappers (Lutjanidae), groupers (Serranidae), cobia (Rachycentridae), sharks, and rays (Elasmobranch). The demersal fish community structures in the huge area of the continental shelf part of the Arafura Sea are likely to be differ in term of its dominant composition. Based on catch composition data during this cruise the bottom long line catch in the flat area in term of weight was dominated by the group of red snappers, while in the slope area was dominated by the groupers. The red snappers in the slope area represent only the third dominant species group. In term of numbers the most dominant fish group in the slope area was sharks and rays, while in the flat area was still dominated by the red snappers. From this composition data it can be concluded that more than $75 \%$ of bottom long line catches consisted of red snappers, groupers and sharks \& rays (Table 2 ). The most dominated red snappers species found in the catch were goldband snappers, Pristipomoides spp. ( $P$. multidens and $P$. typus), red snappers, Lutjanus spp., jobfish (Etelis carbunculus), john snapper ( $L$. johni) and emperor red snapper (L. sebae), while groupers consisted of Epinephelus microdon, Epinephelus amblycephalus, Epinephelus maculatus, and Epinephelus retouti. Goldband snappers are typical deepwaters fish found in the Arafura Sea, the Timor Sea (Ramm, 1995) and the Pacific islands (King, 1986).

Table 2. Bottom long line catch composition by major catagories in the Arafura Sea

\begin{tabular}{lcccc}
\hline \multicolumn{1}{c}{ Fish group } & \multicolumn{2}{c}{ Slope area } & \multicolumn{2}{c}{ Flat area } \\
& W (\%) & $\mathrm{N} \mathrm{( \% )}$ & W (\%) & $\mathrm{N}(\%)$ \\
\hline Red snappers & 23.0 & 14.7 & 40.0 & 38.3 \\
Groupers & 39.1 & 23.3 & 22.5 & 13.7 \\
Cobia & 7.3 & 7.9 & 13.4 & 11.2 \\
Shark \& Rays & 26.3 & 49.3 & 18.5 & 30.1 \\
Miscellaneous & 4.3 & 4.8 & 5.6 & 6.7 \\
\hline Total (\%) & 100.0 & 100.0 & 100.0 & 100.0 \\
\hline Total catch & 16,917 & 6,715 & 4,548 & 1,585 \\
\hline
\end{tabular}

Note: "W in kgs, $N=$ Numbers

Table 3. Number of fish and average individual fish weight caught by bottom long line in the Arafura Sea

\begin{tabular}{|c|c|c|c|c|c|c|}
\hline \multirow{2}{*}{ Fish group } & \multicolumn{3}{|c|}{ Slope area } & \multicolumn{3}{|c|}{ Flat area } \\
\hline & W & $N$ & $x^{*}$ & W & $\mathrm{N}$ & $x^{*}$ \\
\hline Red snappers & 3,891 & 987 & 3.9 & 1,819 & 607 & 3.0 \\
\hline Groupers & 6,615 & 1,564 & 4.2 & 1,023 & 217 & 4.9 \\
\hline Cobia & 1,235 & 530 & 2.3 & 609 & 178 & 3.4 \\
\hline Sharks and Rays & 4,449 & 3,310 & 1.3 & 841 & 493 & 1.7 \\
\hline
\end{tabular}

Notes: ") Average individual fish weight 
Cobia or black kingfish consisted of only one species Rachycentron canadus while the two dominant species group of sharks were hammerhead shark (Sphyrna lewini) and Squallus spp., the most popular shark targetted mainly for the purpose of getting squalen oil.

The fishes caught in a relatively small amount were grouped into miscellaneous fish. These groups consisted of emperors, Lethrinus spp., naked-headed sea-bream, Gymnocranius griseus, catfish, Arius spp., conger-eels, Congridae, and pike-eels, Muraenesocidae.

Looking at the weight and numbers data of the red snappers and the groupers it is likely that this two fish group having different behavioural habitat. The average individual size of red snappers in the slope area are likely to be bigger compare with those inhabiting the flat area. On the other hand, the individual size of groupers inhabiting the flat area seem to be bigger compare with those inhabiting the slope area. Similarly the bigger average individual sizes of cobia and sharks \& rays were likely occurred in the flat area (Table 3). The differences in fish and shrimp behaviour provide a general phenomena occurring along their life cycles, where each stage of development will need different environmental conditions (Badrudin \& Wudianto, 2004; Garcia \& Le Reste, 1981; Thompson \& Munro, 1983; Thompson \& Munro, 1983a; Gaut \& Munro, 1983).

Bottom long lining for demersal large finfish in the Arafura Sea seemed to be having good prospect in the slope area, as this area is considered lightly exploited at least in the period 2004/2005. Other selective fishing gear that need to be explored in this area is trap. Fishing trials using traps, such as done nowadays by the fishers based in Kejawanan (Cirebon, West Java) need to be encouragely carried out.

\section{CONCLUSION}

Based on exploratory bottom long lining that randomly operated, it was later found that 16 fishing stations were carried out in the flat part of the continental shelf area and 13 stations in the slope area.

Catch rate in the slope of about 1.3 tonnes/setting was more than four and half times higher than the catch rate in the flat area which was only about 0.28 tonnes. Higher variation of catch/setting in the flat area was occurred, while in the slope area was relatively lower. The hook rate in the flat area was only 1.02 (one fish) or $2.8 \mathrm{kgs}$, while in the slope area was 5.63 ( 6 fish) or $14.2 \mathrm{kgs}$ per 100 hooks.

From these composition data it can be concluded that more than $75 \%$ of bottom long line catches consisted of red snappers, groupers and sharks and rays. The most dominated red snappers species found in the catch were goldband snappers, Pristipomoides spp. ( $P$. multidens and $P$. typus), deep-water snapper, jobfish Etelis carbunculus, while groupers consisted of Epinephelus microdon, Epinephelus amblycephalus, Epinephelus maculatus, Epinephelus retouti

The average individual size (weight) of red snappers in the slope area are likely to be bigger compare with those inhabiting the flat area. On the other hand, the individual size of groupers inhabiting the flat area seem to be bigger compare with those inhabiting the slope area. Similarly the relatively bigger average individual sizes of cobia and sharks and rays were likely occurred in the flat area.

\section{REFERENCES}

Aoyama, T. 1973. The demersal fish stock and fisheries of the South China Sea. SCS/DEV/73/3 FAO-UN. Rome. 80p.

Badrudin, S. Nurhakim, \& B. Fegan. 2004. Catch rate and catch composition of trawl-fish net in the Arafura Sea. Indonesian Fish.Res.Jour. Vol. 10 (1) : 1-7.

Badrudin, B. Sumiono, \& S. Nurhakim. 2004a. Hook rates and compositions of bottom long line catches in the waters of the Arafura Sea. Indonesian Fish. Res. Jour. Vol. 10 (1) : 9-14.

Badrudin \& Wudianto. 2004. Biology, habitat, and distribution of hair-tail and its fisheries aspects. Paper presented at the Workshop of Hair-tail Fisheries Management Plan-1. Kediri, Juli, 2004. Trenggalek District of Marine and Fisheries Service/Co-Fish Project. 13p. (In Indonesian).

Badrudin, B. Sumiono, \& N. Wirdaningsih. 2002. Catch rate, maximum catch (MSY), and optimum effort of the shrimp fisheries in the Arafura Sea. Indonesian Fish.Res.Jour. Vol. 8 (4):23-30. (In Indonesian).

Badrudin \& B. Sumiono. 2002. Stock abundance index and proportion of shrimp in the demersal community in the waters of Aru islands, Arafura Sea. Indonesian Fish. Res.Jour. Vol. 8 (1) : 95-102. (In Indonesian)

FAO. 1995. Code of conduct for responsible fisheries. FAO-UN. $41 p$

Garcia, S. \& L. Le Reste. 1981. Life cycles, dynamics, exploitaion and management of coastal penaeid shrimp stocks. FAO Fish. Tech.Pap. No. 203. FAOUN. $215 p$. 
Gaut, V.C. \& J.L. Munro. 1983. The biology, ecology and bionomics of the grunts, Pomdasyidae. In Munro, J.L., (Ed.). 1983. Caribean coral reef fishery resources. ICLARM Studies and Reviews 7. ICLARM. Manila. 276p.

Gulland, J.A. 1993. Fish stock assessment. A manual of basic methods. John Wiley \& Sons.

King, M.G. 1986. The fishery resources of the Pacific islands countries. Part 1. Deepwater shrimp. FAO Fish. Tech.Pap. 272.1. FAO-Rome. 45p.

Ramm, D.C. 1995. Dynamics of the deepwater snapper (Pristipomoides) resource and fishery in Tropical Australia. Joint FFA/SPC Workshop on the management of South Pacific inshore fisheries. Noumea, New Caledonia, 26 June - 7 July 1995. $12 p$

Thompson \& Munro. 1983. The biology, ecology, and bionomics of the hinds and groupers, Serranidae.
In Munro, J.L., (Ed.). 1983. Caribbean coral reef fishery resources. ICLARM Studies and Reviews No. 7. ICLARM. Manila. 276p.

Thompson \& Munro. 1983a. The biology, ecology, and bionomics of the snappers, Lutjanidae. In Munro, J.L., (Ed.). 1983. Caribean coral reef fishery resources. ICLARM Studies and Reviews 7. ICLARM. Manila. 276p.

Unar \& Naamin. 1984. A review of the Indonesian shrimp fisheries and their management. In J.A. Gulland and B.J.Rothschild. 1984 (Eds.). Penaeid shrimp:their biology and management. Fishing News Books Ltd. Great Britain. 308p.

Wibowo, B. 2004. Research on deepsea fish in the Aru and Indian Ocean. Technical Report. Research Center for Capture Fisheries in cooperation with PT. Bahtera Adimina Samudera Ltd. RCCF-AMFR-MMAF. Jakarta. 17p. (In Indonesian) 